\title{
A centennial record of anthropogenic impacts and extreme weather events in southwestern Taiwan: Evidence from sedimentary molecular markers in coastal margin
}

Li-Jung Kuo ${ }^{\mathrm{a}}$, Chon-Lin Lee ${ }^{\mathrm{b}, \mathrm{c}^{*}}$, Patrick Louchouarn ${ }^{\mathrm{d}, \mathrm{e}}$, Chih-An Huh ${ }^{\mathrm{f}}$, James T. Liu ${ }^{\mathrm{g}}$, Jian-Cheng Chen ${ }^{\text {b }}$, Kun-Je Lee ${ }^{\text {b }}$ 


\begin{abstract}
A 100-year history of human and natural disturbances in southwestern Taiwan was reconstructed using a suite of molecular markers in four dated sediment cores from the upper slope region off the Gaoping River mouth. Trends in polycyclic aromatic hydrocarbons (PAHs) tracked Taiwan's industrialization/urbanization starting in the 1970s, and the enactment of environmental regulatory policies thereafter. The predominant pyrogenic sources include vehicular, smelter, and coal combustion but spatial differences are observed among sub-regions of the shelf. Profiles of lignin oxidation products (LOPs) point to a significant increase in terrestrial organic matter inputs driven by land development after the 1970s. Low lignin diagenetic signature ratios $\left[(\mathrm{Ad} / \mathrm{Al})_{\mathrm{v}}\right]$ in all sediments suggest quick transport of fresh plant material from land to sea via mountainous rivers. Shifts in PAHs, LOPs, and radionuclides in recent sediments reveal the deposition of turbidites resulting from typhoon-induced floods. Multiproxy analysis illustrates the interplay between anthropogenic activities and natural processes.
\end{abstract}




\section{Introduction}

Local, regional, and global environmental changes can be driven by dramatic historical shifts in the functioning of human society, such as the industrial revolution, rapid growth in human population, resource extraction and utilization, and recent environmental management practices (Syvitski et al., 2005; Steffen et al., 2007). To understand the history of these human footprints and evaluate the potential anthropogenic impacts to the environments on a large scale, well-preserved natural archives such as ice or sediment cores have proven useful (Van Metre et al., 2000; McConnell et al., 2007; Brandenberger et al., 2008, 2011; Kuo et al., 2011; Louchouarn et al., 2012). These archives also serve as excellent media for the assessment of natural perturbations including episodic events (wildfire, extreme weather, etc.) and long-term climate oscillations (Marlon et al., 2009; Brandenberger et al., 2011; Kuo et al., 2011). Such historical reconstructions allow the benchmarking and long-term assessment of environmental policies/strategies and their influence on reducing the impacts of environmental changes.

To delineate different processes (transport pathways, transformations) and source inputs in environmental archives, different classes of molecular markers are powerful tools because 1) they often are tied to specific sources; 2) change in their internal signatures may be linked to specific alteration processes (bio and physicochemical degradation) or more specific source information; and 3) they can be detected at trace levels (high sensitivity). For example, the presence of specific molecular constituents of the polycyclic aromatic hydrocarbons (PAHs) in the environment can often be correlated with local/regional human activities because they are primarily produced from the 
incomplete combustion of specific fuels or processes (Hites et al., 1980; Van Metre et al., 2000; Fang et al., 2007; Kuo et al., 2011; Louchouarn et al., 2012). Although PAHs may also be derived from petrogenic (oil seepage or spills) or biogenic (diagenesis) sources, the distinct compositional signatures and the applications of diagnostic ratios allow for contaminant source discrimination (Yunker et al., 2002; Jiang et al., 2009), making them ideal markers of the changing impact of industrial and urban activities over the years. Other markers can help characterize natural processes (e.g. transfer of organic matter in watersheds, wildfires) and understand the role and potential influence of human activities on such processes. For example, oxidation products of lignin, the second most abundant biopolymer after cellulose, are important markers of vascular plants and help trace natural and human-driven inputs of terrestrial organic carbon to soils and aquatic systems (Hedges et al., 1982; Louchouarn et al., 1999; Goñi et al., 2000; Farella et al., 2001; Houel et al., 2006; Brandenberger et al., 2011). Anhydrosugars (levoglucosan and its isomers) are byproducts of cellulose combustion and thus are specifically tied to plant biomass combustion (Kuo et al., 2008b, 2011a; Louchouarn et al., 2009). Therefore, their presence in environmental archives can help reconstruct climate or human induced fire events (Kuo et al., 2011b).

Taiwan experienced rapid population and economic growth in the past five decades. A recent survey revealed that the population density of Taiwan (640 Pop. $\mathrm{km}^{-2}$ ) is the $2^{\text {nd }}$ highest in the world among countries with population over 10 millions (Interior National Indicators, Ministry of the Interior). The issue of population density is exacerbated at the regional level, since most people live in the west coastal plains. Kaohsiung City, the largest industrial city in Taiwan, is located in the southwest coastal 
plain, north of the Gaoping River (GPR) mouth. GPR is characterized as a mountainous river draining the largest watershed $\left(3257 \mathrm{~km}^{2}\right)$ in Taiwan resulting in a very high

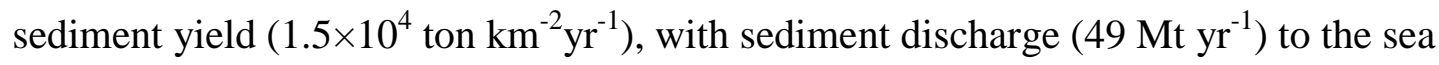
happening mainly during the rainy season (June-October) (Dadson et al., 2003). The combination of intense urban/industrial development and large and rapid transfer of materials through surface runoff along the southwest coastal zone thus suggests that the coastal zone receives large inputs of natural/anthropogenic substances from point and nonpoint sources through river discharge. Our earlier investigations on the spatial distributions of sedimentary PAHs in the surface sediments of this coastal zone have shown that sediments carried clear signatures of local/regional pollution source inputs, which were linked, in some instances, to extreme flood events resulting from typhoons (Fang et al., 2007; Jiang et al., 2009; Lin et al., 2013).

In the present study, four dated sediment cores from the coastal margin off southwestern Taiwan were used to elucidate the history in the past 100 years of regional human development, pollution, and extreme weather events. These sediment cores are located in two major depositional lobes flanking the Gaoping Submarine Canyon (GPSC), $\sim 1 \mathrm{~km}$ seaward off the GPR mouth (Huh et al., 2009) and thus they are considered good archiving materials for detailed historical trend reconstructions for this region. Two distinct classes of molecular markers, PAHs and lignin oxidation products (LOPs), were used to provide insights into the historical inputs of anthropogenic and natural substances. An analysis of spatial differences along the coast is also made through comparison of these four cores. To our knowledge, this is the first report of detailed century-long records of hydrocarbon and lignin inputs to the coastal shelf of southwestern Taiwan. 


\section{Materials and Methods}

\subsection{Sample collection}

The study area and sampling sites are shown in Figure 1. Four sediment cores were collected on the upper slope off the Gaoping River mouth using a box corer onboard research vessel $R / V$ Ocean Researcher-I (OR1) in cruises \#OR1-789 (core L10) and \#OR1-791 (cores L26, L30, and X1) during April 2-14, 2006. Cores L26 and L30 were located north of Gaoping Submarine Canyon (GPSC), whereas X1 and L10 were to the south of GPSC. The water depths at the sampling sites ranged from $\sim 300 \mathrm{~m}$ (cores L26, X1) to $\sim 670 \mathrm{~m}$ (cores L10, L30). After collection, subcores were immediately taken and sectioned at 2-cm intervals throughout the entire core (total length: 32, 40, 34, $42 \mathrm{~cm}$ for L10, L26, L30, X1, respectively). The sectioned sediments were placed into precombusted $\left(450^{\circ} \mathrm{C}\right.$ for $\left.4 \mathrm{~h}\right)$ amber glass bottles and stored at $-20^{\circ} \mathrm{C}$. Sediments were later thawed, filtered through a $1 \mathrm{~mm}$ sieve to remove large detritus, shells and pieces of gravel, and then freeze-dried.

\subsection{Sediment dating}

As described in Huh et al (2009), the dried samples were weighed and transferred to plastic counting jars for non-destructive analysis of ${ }^{210} \mathrm{~Pb}$ and ${ }^{137} \mathrm{Cs}$ using gamma spectrometry. For this study, we used an HPGe detector (ORTEC GMX-100-230) interfaced to a digital spectrometer (DSPec Plus ${ }^{\circledR}$ ). Activities of ${ }^{210} \mathrm{~Pb}$ and ${ }^{137} \mathrm{Cs}$ were determined from the count rate of gamma-ray energies at $46.52 \mathrm{keV}$ and $661.62 \mathrm{keV}$, respectively. In addition, ${ }^{214} \mathrm{~Pb}(351.99 \mathrm{keV})$ was also measured as an index of supported

${ }^{210} \mathrm{~Pb}$, which should be subtracted from the measured ${ }^{210} \mathrm{~Pb}$ so as to obtain excess ${ }^{210} \mathrm{~Pb}$ as 
a sediment chronometer.

\subsection{PAHs analysis}

Dry sediments were extracted using dichloromethane using an accelerated solvent extractor (Dionex ASE 300). Prior to extraction, samples were spiked with perdeuterated PAHs surrogates ( $d_{8}$-naphthalene, $d_{10}$-fluorene, $d_{10}$-fluotanthene, $d_{12}$-perylene). The ASE extraction cell was packed with $6 \%$ deactivated aluminum oxide, glass wool, and sediment-anhydrous sodium sulfate mixture. The obtained extracts were treated with activated copper wool and further concentrated to about $0.5 \mathrm{~mL}$ using rotary evaporator and nitrogen blow-down. Right before analysis, a mixture of perdeuterated PAHs, $d_{10^{-}}$ acenaphthene, $d_{10}$-phenanthrene, $d_{12}$-benzo(a)anthracene, $d_{12}$-benzo(a)pyrene, and $d_{12}$ benzo(g,h,i)perylene was added to each extract as an internal standard.

PAHs were identified and quantified using a gas chromatography-mass spectrometer (Agilent 6890-5973N) operated under selected ion-monitoring mode. A HP5-MS capillary column $(30 \mathrm{~m} \times 0.25 \mathrm{~mm}$ i.d., $0.25 \mu \mathrm{m}$ thickness $)$ was used, with the GC oven temperature programmed from $50^{\circ} \mathrm{C}$ to $280^{\circ} \mathrm{C}$ at $10^{\circ} \mathrm{C} / \mathrm{min}$ and then $280^{\circ} \mathrm{C}$ to $310^{\circ} \mathrm{C}$ at $5^{\circ} \mathrm{C} / \mathrm{min}$. The injector temperature was $310^{\circ} \mathrm{C}$ and helium was used as carrier gas. Data were acquired and processed with the Agilent ChemStation software. Each PAH was identified by its retention time relative to the internal standards and quantified by comparing the integrated area of the molecular ion chromatogram to that of the internal standard. Fifty PAHs (Table S1) were quantified in the present study.

Average percentage recoveries of PAHs surrogates were $60 \pm 4,79 \pm 4,84 \pm 4$, and $70 \pm 5 \%$ for $d_{8}$-naphthalene, $d_{10}$-fluorene, $d_{10}$-fluotanthene, and $d_{12}$-perylene, 
respectively. To avoid overestimation, the PAH concentrations presented in this study were not corrected for surrogate recoveries. Along with each batch of samples, a standard reference material SRM 1941b (Organics in marine sediment, National Institute of Standard Technology, Gaithersburg, MD, USA) was also analyzed for quality assurance and control. The average PAH recovery of the SRM was $90 \pm 29 \%$. The relative percentage differences (RPD) of the duplicate analysis of selected sediment sections were within $11 \%$.

\subsection{Lignin analysis}

For cores L26, L30, and L10, lignin analysis was performed according to the $\mathrm{CuO}$ oxidation method originally developed by Hedges and Ertel (1982) with modifications according to Louchouarn et al. (2000, 2010). Briefly, a sediment amount providing 2-4 $\mathrm{mg}$ OC was oxidized under alkaline conditions with $330 \mathrm{mg} \mathrm{CuO}$ at $155^{\circ} \mathrm{C}$ for $3 \mathrm{~h}$ in pressurized stainless steel mini-reaction vessels ( $3 \mathrm{ml}$; Prime Focus Inc.). Upon oxidation, the lignin macropolymer was hydrolyzed to eight small structural units belonging to three classes of methoxyl phenols: vanillyl (V), syringyl (S), and cinnamyl (C). The resulting lignin oxidation products (LOPs) were derivatized with $\mathrm{N}, \mathrm{O}$ bis(trimethylsilyl)trifluoroacetamide (BSTFA) containing 1\% trimethylchlorosilane (TMCS). Separation and quantification of LOPs were performed on a Varian Ion Trap GC/MS system (3800/4000L) fitted with a fused capillary column (VF-5MS, $60 \mathrm{~m} \times 0.25$ mm i.d.; Varian Inc.). Each sample was injected under splitless injection mode with $\mathrm{He}$ as the carrier gas. The mass spectrometer was operated in the electron impact full scan mode. Compound identification was performed using column retention times and by 
comparing all spectra to those produced by commercially available standards.

Quantification was performed using relative response factors adjusted to trans-cinnamic acid as the internal standard. Replicate analyses of NIST SRM 1941b ( $n=14)$ showed that the analytical precision of the major $\mathrm{CuO}$-oxidation products and related parameters averaged $\sim 5 \%$ with sample precision ranging $5-10 \%$.

\subsection{Multivariate analysis}

The PAHs data set was analyzed with hierarchical cluster analysis (HCA). HCA was used to emphasize natural grouping in the data set. Squared Euclidean distance measurement and Ward's method were used (Savinov et al., 2000) in the present study.

\section{Results and Discussion}

\subsection{Radionuclide profiles}

Unsupported ${ }^{210} \mathrm{~Pb}$ activities in the sediment cores are shown in Figure 2 and

Figure $\mathrm{S} 1$. Abnormally low ${ }^{210} \mathrm{~Pb}$ activities were observed in the surface sediments in all four cores. The low ${ }^{210} \mathrm{~Pb}$ sediment layers are more significant and thicker in the northern cores $(\mathrm{L} 26, \mathrm{~L} 30 ; \sim 6 \mathrm{~cm})$ than in the southern cores $(\mathrm{X} 1, \mathrm{~L} 10 ; \sim 4 \mathrm{~cm})$. One year before the cores were sampled, Taiwan was impacted by super typhoon "Haitang", which brought heavy rainfall in the GPR drainage basin and caused severe floods over southwestern Taiwan. A three-day cumulative rainfall of $1226 \mathrm{~mm}$ was recorded at Alishan weather station, near the headwater of GPR (Huh et al., 2009). Extremely high daily discharge (up to $10467 \mathrm{~m}^{3} \mathrm{~s}^{-1}$ ) and suspended sediment concentration (up to 35000 mg/L) were observed in GPR over that period (7/17 - 7/20/05, Figure S2). These low ${ }^{210} \mathrm{~Pb}$ surface sediments thus are likely representative of the flood layer deposited during 
this typhoon event. Huh et al. (2009) detected significantly depleted ${ }^{210} \mathrm{~Pb}$ and appreciable short-lived ${ }^{7} \mathrm{Be}(\sim 0.5 \mathrm{dpm} / \mathrm{g})$, a useful tracer for flood sedimentation, in the surface sediments of core $\mathrm{X} 1$. The existence of the low ${ }^{210} \mathrm{~Pb}$ activities in these cores thus point to the rapid accumulation of fluvial sediments via gravity flows (turbidite deposits) triggered by typhoon-induced storm flood from GPR, a phenomenon also found in another mountainous river (Liwu River) in northeastern Taiwan (Hilton et al., 2008). The significantly thicker turbidite layer in the northern cores is consistent with the observation that sediments transport on the shelf outside of the submarine canyon is predominantly northwestward (Liu et al., 2002).

Below the flood layers, unsupported ${ }^{210} \mathrm{~Pb}$ activities in all four cores decrease exponentially (Figure 2, S1), suggesting steady sediment accumulation during the period covered. However, significant shifts in the slope of excess ${ }^{210} \mathrm{~Pb}\left({ }^{210} \mathrm{~Pb}\right.$ ex $) v s$. cumulative mass were observed in the two near-shore cores (L26, X1). Both cores have higher accumulation rates in the upper half (L26: $1.24 \mathrm{~g} \mathrm{~cm}^{-2} \mathrm{yr}^{-1}$ from 6-24 $\mathrm{cm}$ depth; X1: 1.64 $\mathrm{g} \mathrm{cm}^{-2} \mathrm{yr}^{-1}$ from 4-18 $\mathrm{cm}$ depth) deposited since the 1980s and lower rates in the lower half (L26: $0.35 \mathrm{~g} \mathrm{~cm}^{-2} \mathrm{yr}^{-1} ; \mathrm{X} 1: 0.41 \mathrm{~g} \mathrm{~cm}^{-2} \mathrm{yr}^{-1}$ ). In the two distal cores (L30 and L10), sediment accumulation rates were consistent throughout the entire core length (L30: 0.25 $\mathrm{g} \mathrm{cm}^{-2} \mathrm{yr}^{-1} ;$ L10: $\left.0.17 \mathrm{~g} \mathrm{~cm}^{-2} \mathrm{yr}^{-1}\right)$. Significantly elevated sediment accumulation rate in L26 and X1 since the 1980s might result from increased land development in the Gaoping River catchment leading to enhanced erosion of soils and hence sediment transport by the river (Syvitski et al., 2005; Horng et al., 2009; Huh et al., 2011).

\subsection{PAH profiles}

\subsubsection{Concentrations and fluxes}


Total PAHs $\left(\mathrm{tPAH}_{50}\right)$ profiles including concentrations and fluxes are shown in Figure 3. Down-core $\mathrm{PPAH}_{50}$ concentrations for all four cores are within a range of 500$1000 \mathrm{ng} \mathrm{g}^{-1} \mathrm{dw}$, except for one extremely high point (1887 $\left.\mathrm{ng} \mathrm{g}^{-1} \mathrm{dw}\right)$ in L30. Due to the distinct sediment accumulation rates in these four cores, the use of accumulation flux is more appropriate for the assessment of PAH inputs at these sites. As shown in Figure 3, L26 has the highest down-core $\mathrm{PAHH}_{50}$ fluxes (236-1221 $\left.\mathrm{ng} \mathrm{cm}^{-2} \mathrm{yr}^{-1}\right)$, followed by X1 (227-1005 $\left.\mathrm{ng} \mathrm{cm}^{-2} \mathrm{yr}^{-1}\right)$, L30 (136-471 $\left.\mathrm{ng} \mathrm{cm}^{-2} \mathrm{yr}^{-1}\right)$, and L10 (87-153 $\left.\mathrm{ng} \mathrm{cm}^{-2} \mathrm{yr}^{-1}\right)$. Evidently, the near-shore cores (L26, X1) have higher $\mathrm{tPAH}_{50}$ fluxes than the two distal cores (L30, L10), but the fluxes in the northern cores are also relatively higher than those in the southern cores $(\mathrm{L} 26>\mathrm{X} 1 ; \mathrm{L} 30>\mathrm{L} 10)$. Such differences may result from a combination of source strength, as well as sediment and atmospheric transport (Liu et al., 2002; Fang et al., 2007, 2009). In order to conduct a fair comparison with reported sedimentary PAH data from other marine systems in the world, we calculated the fluxes of US EPA 16 priority PAHs ( $\mathrm{tPAH}_{16}$ ) (Figure 3), which range from 64-385, 58-301, 38300, and 22-40 $\mathrm{n} \mathrm{cm}^{-2} \mathrm{yr}^{-1}$ for L26, X1, L30, and L10, respectively. The down-core $\mathrm{tPAH}_{16}$ fluxes in $\mathrm{L} 26, \mathrm{X} 1, \mathrm{~L} 30$ are comparable to the values of sediment cores from the Yellow Sea $\left(\sim 50-250 \mathrm{ng} \mathrm{cm}^{-2} \mathrm{yr}^{-1}\right)$ and the South China Sea $\left(\sim 100-250 \mathrm{ng} \mathrm{cm}^{-2} \mathrm{yr}^{-1}\right)$ reported in a recent study (Liu et al., 2012), but are much higher than those from the East China Sea (6-34 $\mathrm{ng} \mathrm{cm}^{-2} \mathrm{yr}^{-1}$, Guo et al., 2006) and southern Lebanese continental margin (1-6 $\mathrm{ng} \mathrm{cm}^{-2} \mathrm{yr}^{-1}$, Azoury et al., 2013).

\subsubsection{Historical trends}

In general, the historical trends of $\mathrm{tPAH}_{50}$ and $\mathrm{tPAH}_{16}$ fluxes are similar in the four cores (Figure 3). Accumulation fluxes of PAHs remained low until the 1970s with 
one peak observed from the 1930s to the early 1940s. This latter peak could be attributed to the construction of a Japanese naval base at Dapeng Bay, located south of the Gaoping River mouth, in the 1930s and the later bombing of the area during WWII. Since the mid-1970s the PAH fluxes increased and reached the down-core maxima near the mid1990s in the northern cores (L26 and L30), while the southern cores (X1 and L10) registered their highest fluxes in the 1980s followed by relatively consistent fluxes through the 1990s. The onset of PAHs increase in the mid-1970s is synchronous with Taiwan's “Ten Major Construction Projects”, in which three projects including ship building (the China Ship Building Corporation), steel making (the China Steel Corporation), and petrochemical industry were all located to the north of Gaoping River mouth (at Linhai and Linyuan Industrial Parks). The period during the 1970s-1980s can be seen as a significant industrialization era of this region. In Kaohsiung City, both population and vehicular number have increased continuously since the early 1980s (Figure S3). The population in Pingtung County, south of Gaoping River mouth, reached a plateau in the early 1990s but is an order of magnitude smaller than the population of the Kaohsiung City. Although the vehicular number in Pingtung County doubled from the 1980 s to the 2000 s, it remained consistently three times lower than that of Kaohsiung City (Figure S3b). This might explain the difference in PAH profiles between the northern and southern cores. After the peak in the 1990s, a decrease of PAH towards the 2000s can be observed in L26, L30, and L10. This is probably due to the enactment of stricter environmental policies since the 1990s such as the Regulation in Air pollution Control Equipment in Vehicle (enacted in 1993) and Marine Pollution Control Act (enacted in 2000; Taiwan EPA, 2014). However, based on PAH signatures (to be 
discussed later), the low PAH concentrations in surface sediments may also be attributed to the quick accumulation of storm-driven mud layers in recent years.

It is worth noting that Horng et al. (2009) applied magnetic and petrographic analyses on sediment cores L26 and X1 to elucidate the historical inputs of magnetic minerals derived from human activities including air pollution history of Kaohsiung City. The down-core profiles of both low-field magnetic susceptibility and saturation isothermal remanent magnetizations (SIRM) in the two cores pointed to a significant peak in the mid-1990s in L26 and a hump in the mid-1980s in X1. These peaks were attributed to the significant inputs of anthropogenic hematite, which might be derived from industrial and vehicular fly ashes. The general trends from magnetic analysis are very similar to the PAH trends in the present study: very low before the 1970s, followed by a significant increase in the 1980s, a peak during the 1980s-1990s and a decrease after the peak. In the surface sediment layers, magnetic minerals are dominated by pyrrhotite, suggesting more rapid deposition of sediments derived from the metamorphic terrain in the Central Range during typhoon Haitang.

The timeframe of the PAH maxima in the studied cores (1980s-1990s) is similar to that recorded in the Yellow Sea (Liu et al., 2012) and slightly later than that (early 1980s) seen in Tokyo Bay (Yamashita et al., 2000). The timing of the PAH maxima in the western Pacific margin is very different from those reported in North America and Europe (spanning from the early 1920s to the late 1950s; Lima et al., 2003; Yan et al., 2005; Elmquist et al., 2007; Kuo et al., 2011b), demonstrating different schedule in industrialization and energy use. While the major PAH decreases in North America and Europe were often attributed to the change of energy consumption pattern from coal to 
petroleum, it was not the case for countries/regions with relatively late development. In Taiwan, petroleum consumption has surpassed coal consumption since the early 1980 s and both coal and petroleum consumptions kept rising into the 2000s (Figure S4). In addition, the coal consumption in coal-fired power plants in Taiwan also continuously increased until 2005 (Energy Statistics Handbook 2012). Apparently, the trend of energy usage is not an overarching factor controlling the PAHs profiles observed here, especially in recent years. Environmental policies and improved combustion technologies may have played more important roles in reducing PAH emissions in Taiwan.

\subsubsection{Potential PAH sources}

PAH diagnostic ratios have been shown to be useful for PAH source identification in environmental samples (Laflamme and Hites, 1978; Dickhut et al., 2000; Yunker et al., 2002; Jiang et al., 2009; Kuo et al., 2011; Louchouarn et al., 2012). The usefulness of a number of proposed diagnostic ratios has been further evaluated in various matrices and even specific regions (Yunker et al., 2002; Jiang et al., 2009). Especially relevant to our work is the conclusion of Jiang et al. (2009) that the ratio of phenanthrene to anthracene (Phe/An; pyrogenic with value $<10$, petrogenic with value $>15$ ) is a very sensitive indicator for petrogenic/pyrogenic source discrimination in a broad coastal area off southwestern Taiwan. As shown in Figure 4, all our cores have high Phe/An values (2030) in deep sediments before 1975 suggesting predominant petrogenic sources. After 1975, the Phe/An values in cores L26, L30, and X1 moved toward pyrogenic sources and peaked synchronously with total PAHs maxima (Figure 3). In contrast to other cores, L10 shows petrogenic PAH inputs throughout the core. In fact, pyrogenic inputs to the 
two southern cores $(\mathrm{X} 1, \mathrm{~L} 10)$ were lower than to the two northern cores (L26, L30). This is consistent with the observations from Fang et al. (2007) that sediments from the southeastern shelf (south of GPR mouth) receive a lower proportion of pyrogenic PAHs than sediments in the northwestern shelf (north of GPR mouth). After the 1990s peaks, the Phe/An values of all four cores moved back to more petrogenic-dominated signatures. Another useful diagnostic ratio $\mathrm{BaA} / 228$ (Benzo[a]anthracene / Benzo[a]anthracene+Chrysene+triphenylene; >0.35: pyrogenic, <0.2: petrogenic) also shows similar PAH source signatures for the four cores, lending further support to the interpretation derived from the Phe/An ratios (Figure S5).

The strong petrogenic signatures in the surface sediments in cores L26 and X1 are intriguing (Phe/An values are similar to the pre-1975 sediments). Although the environmental policies and energy consumption pattern have been documented as a main driver of reduced PAH inputs to the environment (Lima et al., 2003; Elmquist et al., 2007; Kuo et al., 2011b), the development of human society could still prevent PAH signatures from returning to early-time petrogenic sources. Indeed, population and vehicular numbers continue to grow in Kaohsiung City (Figure S3). The dramatic change of PAH sources thus may be the results of unique episodic events. Recently Lin and co-workers (2013) analyzed the PAH signatures of particulate materials deposited in a sediment trap in the Gaoping Submarine Canyon during a typhoon event. They observed a significant change in PAH signature from pyrogenic at the beginning of the flood to predominantly petrogenic by the end of the typhoon event. This later signature was suggested to be from background (pristine) sediments in GPR catchment transported by strong typhooninduced flood. The reduced PAH concentrations and shifts to petrogenic signatures in 
surface layers of the sediment cores of the present study may thus result from the remobilization and rapid deposition of background sediments from GPR catchment rather than any recent improvements in contaminant emissions in the region. Results of hierarchical cluster analysis (HCA) also support the earlier interpretations of the Phe/An profiles (Figures S6). The two near-shore cores (L26 and X1, in Figures S6a and S6b, respectively) each have three major cluster groups showing distinct PAH signatures between surface sections, the mid layers (at the PAH maximum), and the deep sediments.

We further evaluated the potential PAH sources in sections of cores L26, L30, and $\mathrm{X} 1$ where pyrogenic signatures are at their maximum (based on $\mathrm{Ph} / \mathrm{An}$ ratio) via property-property plot of isomer pairs benzo[a]anthracene to chrysene+triphenylene (BaA/Chy) vs. indeno[1,2,3-c,d]pyrene to benzo[g,h,i]perylene (IP/BghiP) (Dickhut et al., 2000). Jiang et al. (2009) suggested that BaA/Chy - IP/BghiP plot offers a strong potential for pyrogenic source discrimination in coastal sediments off SW Taiwan. The results show that vehicular and smelter combustion contributed equally to core L26; while core X1 was influenced more by smelters (Figure 5). Signatures of vehicular combustion also contributed to most of core L30 except at two intervals (4-6 and 6-8 cm) that showed very distinct signatures from coal combustion. The $6-8 \mathrm{~cm}$ section, with extremely high $\mathrm{BaA} / \mathrm{Chy}$ and IP/BghiP values (1.9 and 1.5 , respectively), also contains the highest PAH concentration ( $\mathrm{tPAH}_{16}=1202 \mathrm{ng} / \mathrm{g} \mathrm{dw}$ ). The major individual PAHs in this sediment interval are fluoranthene, pyrene, benzo[a]anthracene, benzo[b]fluoranthene, benzo[a]pyrene, and indeno[1,2,3-c,d]pyrene, which are often predominant in coal combustion emissions (Dickhut et al., 2000; Larsen and Baker, 2003). The combustion sources inferred from the property-property plot (vehicle, smelter, 
coal) are consistent with the industrial activities of the region (steel making, coal-fired power plant, etc.) and with earlier observations of Jiang et al. (2009).

Vertical profiles of perylene in the cores are also worth noting. Perylene was suggested to be generated mainly from post-depositional anaerobic diagenesis of biogenic precursors, either from terrestrial or aquatic sources (Wakeham et al., 1979; Venkatesan, 1988; Jiang et al., 2000; Silliman et al., 2000). It may also be produced from combustion processes but in much lower abundance than other penta-aromatics PAHs (benzo[b]fluoranthene, benzo[k]fluoranthene, benzo[e]pyrene, benzo[a]pyrene). The ratio of perylene to the sum of penta-aromatics PAHs was proposed as an indicator of potential contribution of diagenetic inputs ( $<10 \%$ : pyrogenic dominated; $>10 \%$ : relatively higher influence of diagenesis; Readman et al., 2002; Chen et al., 2006). This indicator in the four cores (Figure 6) clearly shows higher values (40-60\%) in the deep sediments (pre-1975), pointing to the predominance of diagenesis as a source of this PAH in sediments deposited prior to 1970 . Decreasing values for this ratio were found for all cores along the time frame corresponding to the down-core PAH maxima around the 1980s and the 1990s (Figure 3), confirming the shift to pyrogenic PAH inputs during that period (Figure 4). The lowest Perylene/ penta-PAHs value $(\sim 10 \%)$ was found during the PAH maximum of core L30, synchronous with the highest recorded PAHs concentrations and the most unambiguous pyrogenic signatures in all core intervals (Figures 4, 5).

Finally, the surface sediments of all four cores show low perylene/乏penta-PAHs values. The influences of pyrogenic inputs should be insignificant, based on other PAH diagnostic ratios (Figures 4, S5). There are two plausible explanations: 1) those sediments are relatively "new" without post-depositional alteration; and 2) they actually 
represent the signature of typhoon-induced flood deposits because low perylene/ $\Sigma$ pentaPAHs ratio was also suggested as a feature of background (pristine) GPR sediments (Lin et al., 2013).

\subsection{Terrestrial organic matter inputs}

\subsubsection{Historical trends}

The history of terrestrial organic matter inputs over the coastal margin off SW Taiwan was illustrated by vertical profiles of lignin oxidation products (LOPs) in cores L26, L30, and L10 (Figure 7a). These three cores show similar $\Lambda 8$ values (OCnormalized sum of eight primary LOP) prior to 1975 (0.2-0.4 mg/100mg OC) except for a peak in L10 around the turn of the $20^{\text {th }}$ century. Significant increases of $\Lambda 8$ were observed for all three cores starting from the early $1980 \mathrm{~s}$ (at $0.2-0.3 \mathrm{mg} / 100 \mathrm{mg}$ OC) and reaching values $2-3$ times higher $(0.8-1.0 \mathrm{mg} / 100 \mathrm{mg} \mathrm{OC})$ in surface sediments. The timing of the $\Lambda 8$ increase is here again consistent with the major industrial development and economic boom of the region. Rapid urban and industrial development in a region often involves large-scale changes in land-use including land clearance leading to the release of terrestrial organic matter to receiving aquatic systems (Brandenberger et al., 2008, 2011). Another human activity that often contributes to the significant terrestrial

OM inputs is deforestation (Farella et al., 2001; Brandenberger et al., 2008, 2011). Taiwan was under a deforestation-based forest management policy until 1991 and the forest coverage in Taiwan was reduced from $~ 90 \%$ to $52 \%$ in a few decades during the $20^{\text {th }}$ century (Chen et al., 2004).

The $\Lambda 8$ maxima in all three cores occur near the surface sediments $c a .2005$. We 
believe that such major enrichment in terrestrial OM results from enhanced soil erosion and sediment transport from land to the sea by super typhoon Haitang. In Taiwan, heavy rainfalls are often associated with typhoons. The typhoon-induced landslides over the forested hillslopes can deliver large quantities of vascular plant biomass debris (enriched in lignin) to river channels and then to the coastal environment (Milliman and Kao, 2005; Hilton et al., 2008, 2011; Liu et al., 2013). Both typhoon-induced episodic flash floods and hyperpycnal flows have been suggested as important processes for terrestrial OM transport from land to sea in this region (Hilton et al., 2008; Liu et al., 2013). Vertical $\Lambda 8$ profiles in the present study thus point to the influence of both social development and episodic climatic events on the transport and burial of terrestrial OM in coastal waters. Besides higher $\Lambda 8$ at the tops of all cores, there exists a broad $\Lambda 8$ peak at depth in core L10 (Figure 7a). Based on sediment chronology derived from ${ }^{210} \mathrm{~Pb}$ and very well constrained by ${ }^{137} \mathrm{Cs}$, the subsurface $\Lambda 8$ peak spans a period of $\sim 45$ years around the turn of the $20^{\text {th }}$ century. Thus, it could be a manifestation of major land clearance activities that occurred when Taiwan was governed by the Qing dynasty and later colonized by Japan (1895-1945).

\subsubsection{Signatures of LOPS}

Internal parameters based on specific LOPs are very useful tools for assessing potential lignin sources such as taxonomic vascular plant groups (gymnosperms $v s$. angiosperms), tissue type (soft tissues vs. woody tissues), and diagenetic state or alteration of the original lignin material (Hedges et al., 1988; Goñi et al., 1992; Opsahl and Benner, 1995; Louchouarn et al., 1999; Houel et al., 2006). The ratio of syringyl (S) to vanillyl (V) phenols (S/V) offers discriminatory potential between angiosperm and 
gymnosperm source inputs ( $\mathrm{S} / \mathrm{V}<0.2$ and $\mathrm{S} / \mathrm{V}>1$, respectively); while the ratio of cinnamyl $(\mathrm{C})$ to vanillyl phenols $(\mathrm{C} / \mathrm{V})$ is sensitive to the inputs of non-woody materials such as herbaceous and soft tissues (i.e. leaves and needles $\mathrm{C} / \mathrm{V}>0.2$ ). The propertyproperty plot of S/V vs. C/V (Figure 8) clearly shows that angiosperm woods are the primary lignin source. Sediments in L26 and L30 have very similar S/V-C/V signatures, while sediments in L10 exhibit slightly lower S/V values compared to other two cores suggesting a mixture with some gymnosperm or slightly altered material (Louchouarn et al., 1999). The strong drop in S/V signature right below the surface interval of core L10 is associated with a significant decrease in lignin concentrations (Figures 7, 8, Table S2). This interval is part of the turbidite bed and characterized by the coarsest particle size in the deposit. Such lignin signatures point to a very different source material from the lignin-enriched finer particle layer above it, and demonstrate the potential variance of TOM signatures within a turbidite sequence due to particle sorting during the turbidite deposition processes.

The ratio of acid to aldehyde phenols ( $\mathrm{Ad} / \mathrm{Al}$ ) of vanillyl phenols is often used to assess the state of oxidative degradation of lignin constituents, either microbial and/or photochemical, of parent lignin polymer (Hedges et al., 1988; Goñi et al., 1993; Opsahl and Benner, 1995, 1998). Profiles of $(\mathrm{Ad} / \mathrm{Al})_{\mathrm{v}}$ in three cores (Figure $\left.7 \mathrm{~b}\right)$ show a narrow range (0.4-0.7), suggesting that the lignin materials associated with these sediments were relatively fresh or only altered mildly prior to deposition (Hedges and Mann, 1979; Goñi et al., 1993). Hale et al. (2012) studied the lignin signatures in sediment cores from Fangliao submarine canyon, located south of Gaoping submarine canyon, and found similar $(\mathrm{Ad} / \mathrm{Al})_{\mathrm{v}}$ values $(0.2-0.6)$. Most rivers in Taiwan are classified as small 
mountainous rivers (SMRs), featuring steep gradients, relatively low sediment storage capacity, and short distances from headwater to river mouth (Milliman and Syvitski, 1992). Gaoping River is a SMR and the relatively short sediment transport time might explain the observed low $(\mathrm{Ad} / \mathrm{Al})_{\mathrm{v}}$ ratios in these sediment cores. It has now been well recognized that SMRs play an important role in the transport of sediment and terrestrial particulate OC to continental slopes and beyond (Kao and Liu, 1996; Komada et al, 2004; Hilton et al., 2011; Goñi et al, 2013; Liu et al., 2013). Our data provide further molecular information supporting rapid burial of terrestrial OM transported by SMRs in SW Taiwan.

\section{Acknowledgments}

The authors acknowledge financial support from the National Science Council and the Ministry of Education of Taiwan, R.O.C, under Contract Numbers NSC 97-2611-M-110008, NSC 101-2611-M-110-012 and DOE 99C0302. We also thank the Sediment Trap Laboratory of the National Center for Ocean Research for the sample collection. $R / V$ Ocean Research I was used in the fieldwork.

\section{References:}

Azoury, S., Tronczynski, J., Chiffoleau, J.-F., Cossa, D., Nakhle, K., Schmidt, S., Khalaf, G., 2013. Historical records of mercury, lead, and polycyclic aromatic hydrocarbons depositions in a dated sediment core from the eastern Mediterranean. Environ. Sci. Technol. 47, 7101-7109.

Brandenberger, J.M., Crecelius, E.A., Louchouarn, P., 2008. Historical inputs and natural recovery rates for heavy metals and organic biomarkers in Puget Sound during the 20th century. Environ. Sci. Technol. 42, 6786-6790.

Brandenberger, J.M., Louchouarn, P., Crecelius, E.A., 2011. Natural and posturbanization signatures of hypoxia in two basins of Puget Sound: Historical reconstruction of redox sensitive metals and organic matter inputs. Aquat Geochem 17, 645-670. 
Energy Statistics Handbook 2012 (second edition), Bureau of Energy, Taiwan, August 2013.

Chen, C.-T.A., Liu, J.T., Tsuang, B.-J., 2004. Island-based catchment - The Taiwan example. Reg. Environ. Change 4, 39-48.

Chen, S.J., Luo, X.J., Mai, B.X., Sheng, G.Y., Fu, J.M., Zeng, E.Y., 2006. Distribution and mass inventories of polycyclic aromatic hydrocarbons and organochlorine pesticides in sediments of the Pearl river estuary and the northern South China Sea. Environ. Sci. Technol. 40, 709-714.

Dadson, S.J., Hovius, N., Chen, H., Dade, W.B., Hsieh, M.-L., Willett, S.D., Hu, J.-C., Horng, M.-J., Chen, M.-C., Stark, C.P., Lague, D., Lin, J.-C., 2003. Links between erosion, runoff variability and seismicity in the Taiwan orogen. Nature $426,648-651$.

Dickhut, R.M., Canuel, E.A., Gustafson, K.E., Liu, K., Arzayus, K.M., Walker, S.E., Edgecombe, G., Gaylor, M.O., Macdonald, E.H., 2000. Automotive sources of carcinogenic polycyclic aromatic hydrocarbons associated with particulate matter in the Chesapeake Bay region. Environ. Sci. Technol. 34, 4635-4640.

Elmquist, M., Zencak, Z., Gustafsson, Ö., 2007. A 700 year sediment record of black carbon and polycyclic aromatic hydrocarbons near the EMEP air monitoring station in Aspvreten, Sweden. Environ. Sci. Technol. 41, 6926-6932.

Fang, M.-D., Chang, W.-K., Lee, C.-L., Liu, J.T., 2009. The use of polycyclic aromatic hydrocarbons as a particulate tracer in the water column of Gaoping (Kaoping) Submarine Canyon. J. Marine Syst. 76, 457-467.

Fang, M.-D., Hsueh, P.-C., Ko, F.-C., Baker, J.E., Lee, C.-L., 2007. Sources and distribution of polycyclic aromatic hydrocarbons in the sediments of Kaoping river and submarine canyon system, Taiwan. Mar. Pollut. Bull. 54, 1179-1189.

Farella, N., Lucotte, M., Louchouarn, P., Roulet, M., 2001. Deforestation modifying terrestrial organic transport in the Rio Tapajos, Brazilian Amazon. Org. Geochem. 32, 1443-1458.

Goñi, M.A., Hatten, J.A., Wheatcroft, R.A., Borgeld, J.C., 2013. Particulate organic matter export by two contrasting small mountainous rivers from the Pacific Northwest, U.S.A. J. Geophys. Res.: Biogeosciences 118, 112-134. 
Goñi, M.A., Hedges, J.I., 1992. Lignin dimers; structures, distribution, and potential geochemical applications. Geochim. Cosmochim. Acta 56, 4025-4043.

Goñi, M.A., Nelson, B., Blanchette, R.A., Hedges, J.I., 1993. Fungal degradation of wood lignins; Geochemical perspectives from $\mathrm{CuO}$-derived phenolic dimers and monomers. Geochim. Cosmochim. Acta 57, 3985-4002.

Goñi, M.A., Yunker, M.B., Macdonald, R.W., Eglinton, T.I., 2000. Distribution and sources of organic biomarkers in arctic sediments from the Mackenzie River and Beaufort Shelf. Mar. Chem. 71, 23-51.

Gschwend, P.M., Chen, P.H., Hites, R.A., 1983. On the formation of perylene in recent sediments: kinetic models. Geochim. Cosmochim. Acta 47, 2115-2119.

Guo, Z., Lin, T., Zhang, G., Yang, Z., Fang, M., 2006. High-resolution depositional records of polycyclic aromatic hydrocarbons in the central continental shelf mud of the East China Sea. Environ. Sci. Technol. 40, 5304-5311.

Hale, R.P., Nittrouer, C.A., Liu, J.T., Keil, R.G., Ogston, A.S., 2012. Effects of a major typhoon on sediment accumulation in Fangliao Submarine Canyon, SW Taiwan. Mar. Geol. 326-328, 116-130.

Hedges, J.I., Clark, W.A., Cowie, G.L., 1988. Organic matter sources to the water column and surficial sediments of a marine bay. Limnol. Oceanogr. 33, 11161136.

Hedges, J.I., Ertel, J.R., 1982. Characterization of lignin by gas capillary chromatography of cupric oxide oxidation products. Anal. Chem. 54, 174-178.

Hedges, J.I., Ertel, J.R., Leopold, E.B., 1982. Lignin geochemistry of a late Quaternary sediment core from Lake Washington. Geochim. Cosmochim. Acta 46, 18691877.

Hedges, J.I., Mann, D.C., 1979. The lignin geochemistry of marine sediments from the southern Washington coast. Geochim. Cosmochim. Acta 43, 1809-1818.

Hilton, R.G., Galy, A., Hovius, N., Chen, H.-C., Horng, M.-J., Chen, H., 2008. Tropicalclone-driven erosion of the terrestrial biosphere from mountains. Nat. Geosci. 1, 759-763. 
Hilton, R.G., Galy, A., Hovius, N., Horng, M.-J., Chen, H., 2011. Efficient transport of fossil organic carbon to the ocean by steep mountain rivers: An orogenic carbon sequestration mechanism. Geology 39, 71-74.

Hites, R.A., Laflamme, R.E., Windsor Jr, J.G., Farrington, J.W., Deuser, W.G., 1980.

Polycyclic aromatic hydrocarbons in an anoxic sediment core from the Pettaquamscutt River (Rhode Island, U.S.A.). Geochim. Cosmochim. Acta 44, 873-878.

Horng, C.-S., Huh, C.-A., Chen, K.-H., Huang, P.-R., Hsiung, K.-H., Lin, H.-L., 2009. Air pollution history elucidated from anthropogenic spherules and their magnetic signatures in marine sediments offshore of Southwestern Taiwan. J. Marine Syst. 76, 468-478.

Houel, S., Louchouarn, P., Lucotte, M., Canuel, R., Ghaleb, B., 2006. Translocation of soil organic matter following reservoir impoundment in boreal systems: Implications for in situ productivity. Limnol. Oceanogr. 51, 1497-1513.

Huh, C.-A., Lin, H.-L., Lin, S., Huang, Y.-W., 2009. Modern accumulation rates and a budget of sediment off the Gaoping (Kaoping) River, SW Taiwan: A tidal and flood dominated depositional environment around a submarine canyon. J. Marine Syst. 76, 405-416.

Huh, C.-A., Chen W., Hsu, F.-H., Su, C.-C., Chiu, J.-K., Lin S., Liu, C.-S., Huang, B.-J., 2011. Modern ( $<100$ years) sedimentation in the Taiwan Strait: Rates and sourceto-sink pathways elucidated from radionuclides and particle size distribution. Cont. Shelf Res. 31, 47-63.

Interior National Indicators, Department of Statistics, Ministry of the Interior, Taiwan (http://www.moi.gov.tw/stat/english/interior.asp). Viewed on Jan 2014.

Jiang, C., Alexander, R., Kagi, R.I., Murray, A.P., 2000. Origin of perylene in ancient sediments and its geological significance. Org. Geochem. 31, 1545-1559.

Jiang, J.-J., Lee, C.-L., Fang, M.-D., Liu, J.T., 2009. Polycyclic aromatic hydrocarbons in coastal sediments of southwest Taiwan: An appraisal of diagnostic ratios in source recognition. Mar. Pollut. Bull. 58, 752-760.

Komada, T., Druffel, E.R.M., Trumbore, S.E., 2004. Oceanic export of relict carbon by small mountainous rivers. Geophys. Res. Lett. 31, L07504. 
Kuo, L.-J., Herbert, B.E., Louchouarn, P., 2008a. Can levoglucosan be used to characterize and quantify char/charcoal black carbon in environmental media? Org. Geochem. 39, 1466-1478.

Kuo, L.-J., Louchouarn, P., Herbert, B.E., 2008b. Fate of CuO-derived lignin oxidation products during plant combustion: Application to the evaluation of char input to soil organic matter. Org. Geochem. 39, 1522-1536.

Kuo, L.-J., Louchouarn, P., Herbert, B.E., 2011a. Influence of combustion conditions on yields of solvent-extractable anhydrosugars and lignin phenols in chars: Implications for characterizations of biomass combustion residues. Chemosphere $85,797-805$.

Kuo, L.-J., Louchouarn, P., Herbert, B.E., Brandenberger, J.M., Wade, T.L., Crecelius, E.A., 2011b. Combustion-derived substances in deep basins of Puget Sound: Historical inputs from fossil fuel and biomass combustion. Environ. Pollut. 159, 983-990.

Larsen, R.K., Baker, J.E., 2003. Source apportionment of polycyclic aromatic hydrocarbons in the urban atmosphere: A comparison of three methods. Environ. Sci. Technol. 37, 1873-1881.

Lima, A.L., Eglinton, T.I., Reddy, C.M., 2003. High-resolution record of pyrogenic polycyclic aromatic hydrocarbon deposition during the 20th century. Environ. Sci. Technol. 37, 53-61.

Lin, B.-S., Brimblecombe, P., Lee, C.-L., Liu, J.T., 2013. Tracing typhoon effects on particulate transport in a submarine canyon using polycyclic aromatic hydrocarbons. Mar. Chem. 157, 1-11.

Liu, J.T., Kao, S.-J., Huh, C.-A., Hung, C.-C., 2013. Gravity flows associated with flood events and carbon burial: Taiwan as instructional source area. Annu. Rev. Mar. Sci. 5, 47-68.

Liu, J.T., Liu, K.-J., Huang, J.C., 2002. The effect of a submarine canyon on the river sediment dispersal and inner shelf sediment movements in southern Taiwan. Mar. Geol. 181, 357-386.

Liu, L.-Y., Wang, J.-Z., Wei, G.-L., Guan, Y.-F., Wong, C.S., Zeng, E.Y., 2012. Sediment records of polycyclic aromatic hydrocarbons (PAHs) in the continental 
shelf of China: Implications for evolving anthropogenic impacts. Environ. Sci. Technol. 46, 6497-6504.

Louchouarn, P., Amon, R.M.W., Duan, S., Pondell, C., Seward, S.M., White, N., 2010. Analysis of lignin-derived phenols in standard reference materials and ocean dissolved organic matter by gas chromatography/tandem mass spectrometry. Mar. Chem. 118, 85-97.

Louchouarn, P., Kuo, L.-J., Brandenberger, J.M., Marcantonio, F., Garland, C., Gill, G.A., Cullinan, V., 2012. Pyrogenic Inputs of Anthropogenic $\mathrm{Pb}$ and $\mathrm{Hg}$ to Sediments of the Hood Canal, Washington, in the 20th Century: Source Evidence from Stable Pb Isotopes and PAH Signatures. Environ. Sci. Technol. 46, 5772-5781.

Louchouarn, P., Kuo, L.-J., Wade, T.L., Schantz, M., 2009. Determination of levoglucosan and its isomers in size fractions of aerosol standard reference materials. Atmos. Environ. 43, 5630-5636.

Louchouarn, P., Lucotte, M., Farella, N., 1999. Historical and geographical variations of sources and transport of terrigenous organic matter within a large-scale coastal environment. Org. Geochem. 30, 675-699.

Louchouarn, P., Opsahl, S., Benner, R., 2000. Isolation and quantification of dissolved lignin from natural waters using solid-phase extraction and GC/MS. Anal. Chem. 72, 2780-2787.

Marlon, J.R., Bartlein, P.J., Walsh, M.K., Harrison, S.P., Brown, K.J., Edwards, M.E., et al., 2009. Wildfire responses to abrupt climate change in North America. Proc. Natl. Acad. Sci. U.S.A. 106, 2519-2524.

McConnell, J.R., Edwards, R., Kok, G.L., Flanner, M.G., Zender, C.S., Saltzman, E.S., Banta, J.R., Pasteris, D.R., Carter, M.M., Kahl, J.D.W., 2007. 20th-century industrial black carbon emissions altered Arctic climate forcing. Science 317, 1381-1384.

Milliman, J.D., Kao, S.-J., 2005. Hyperpycnal discharge of fluvial sediment to the ocean: Impact of super-typhoon Herb (1996) on Taiwanese rivers. J. Geol. 113, 503-516.

Milliman, J.D., Syvitski, J.P.M., 1992. Geomorphic/tectonic control of sediment discharge to the ocean: The importance of small mountainous rivers. J. Geol. 100, 525-544. 
Opsahl, S., Benner, R., 1995. Early diagenesis of vascular plant-tissues - Lignin and cutin decomposition and biogeochemical implications. Geochim. Cosmochim. Acta 59, 4889-4904.

Opsahl, S., Benner, R., 1998. Photochemical reactivity of dissolved lignin in river and ocean waters. Limnol. Oceanogr. 43, 1297-1304.

Readman, J.W., Mantoura, R.F.C., Rhead, M.M., 1987. A record of polycyclic aromatic hydrocarbon $(\mathrm{PAH})$ pollution obtained from accreting sediments of the Tamar Estuary, UK - evidence for nonequilibrium behavior of PAH. Sci. Total Environ. 66, 73-94.

Savinov, V.M., Savinova, T.N., Carroll, J., Matishov, G.G., Dahle, S., Naes, K., 2007. Polycyclic aromatic hydrocarbons (PAHs) in sediments of the White Sea, Russia. Mar. Pollut. Bull. 40, 807-818.

Silliman, J.E., Meyers, P.A., Ostrom, P.H., Ostrom, N.E., Eadie, B.J., 2000. Insights into the origin of perylene from isotopic analyses of sediments from Saanich Inlet, British Columbia. Org. Geochem. 31, 1133-1142.

Steffen, W., Crutzen, P.J., McNeill, J.R., 2007. The Anthropocene: Are humans now overwhelming the great forces of nature? Ambio 36, 614-621.

Syvitski, J.P.M., Vorosmarty, C.J., Kettner, A.J., Green, P., 2005. Impact of humans on the flux of terrestrial sediment to the global coastal ocean. Science 308, 376-380.

Taiwan EPA website. Available from: http://ivy5.epa.gov.tw/epalaw/index.aspx

Van Metre, P.C., Mahler, B.J., Furlong, E.T., 2000. Urban sprawl leaves its PAH signature. Environ. Sci. Technol. 34, 4064-4070.

Venkatesan, M.I., 1988. Occurrence and possible sources of perylene in marine sediments-a review. Mar. Chem. 25, 1-27.

Wakeham, S.G., SchaÄner, C., Giger, W., Boon, J.J., De Leeuw, J.W., 1979. Perylene in sediments from the Namibian Shelf. Geochim. Cosmochim. Acta 43, 1141-1144.

Wakeham, S.G., Schaffner, C., Giger, W., 1980. Polycyclic aromatic-hydrocarbons in recent lake sediments .1. Compounds having anthropogenic origins. Geochim. Cosmochim. Acta 44, 403-413.

Yamashita, N., Kannan, K., Imagawa, T., Villeneuve, D.L., Hashimoto, S., Miyazaki, A., Giesy, J.P., 2000. Vertical profiles of polychlorinated dibenzo-p-dioxins, 
dibenzofurans, naphthelenes, biphenyls, polycyclic aromatic hydrocarbons, and alkylphenols in a sediment core from Tokyo Bay, Japan. Environ. Sci. Technol. 34, 3560-3567.

Yan, B.Z., Abrajano, T.A., Bopp, R.F., Chaky, D.A., Benedict, L.A., Chillrud, S.N., 2005. Molecular tracers of saturated and polycyclic aromatic hydrocarbon inputs into Central Park Lake, New York City. Environ. Sci. Technol. 39, 7012-7019.

Yunker, M.B., Macdonald, R.W., Vingarzan, R., Mitchell, R.H., Goyette, D., Sylvestre, S., 2002. PAHs in the Fraser River basin: a critical appraisal of PAH ratios as indicators of PAH source and composition. Org. Geochem. 33, 489-515. 


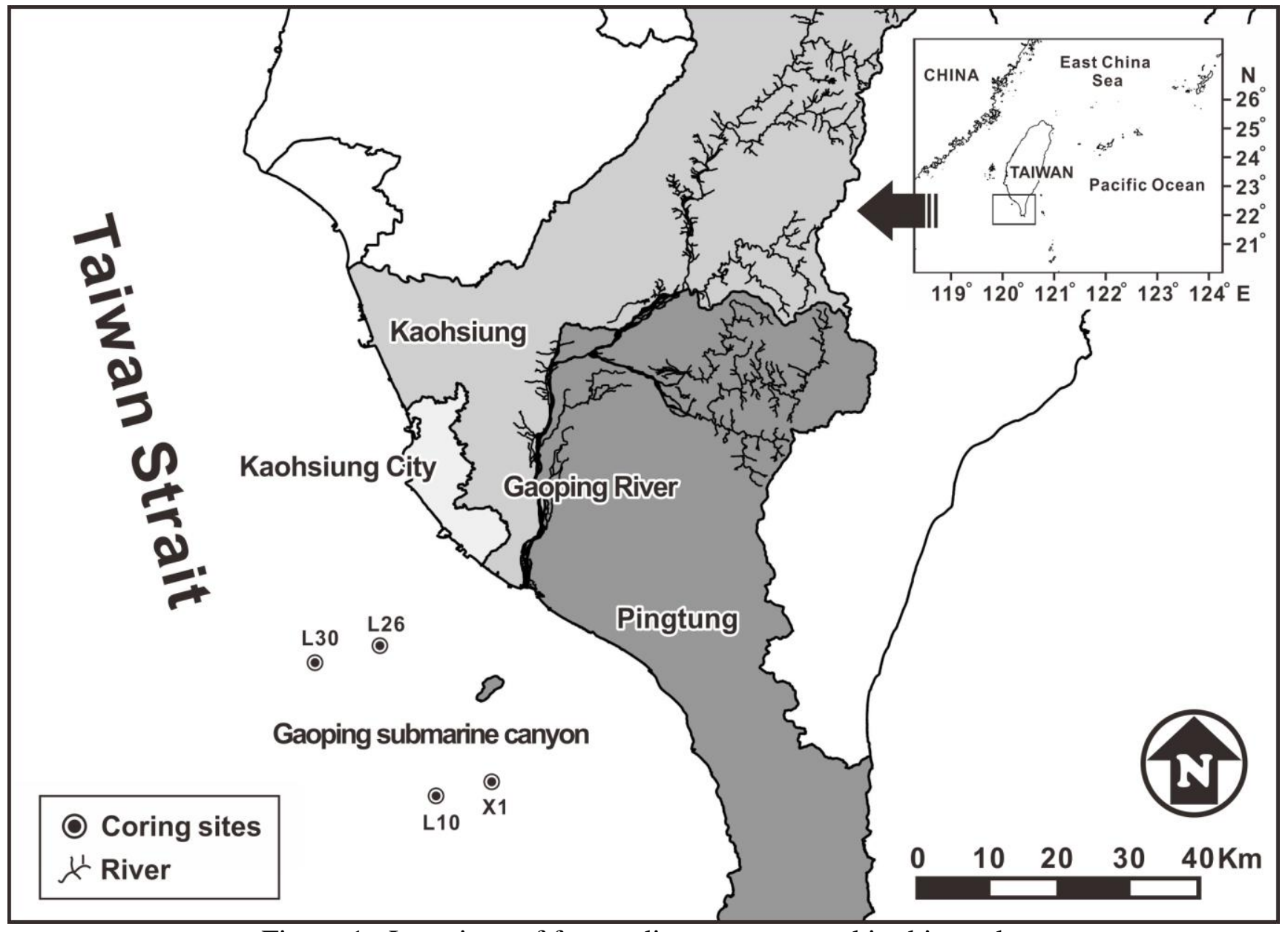

Figure 1. Locations of four sediment cores used in this study. 

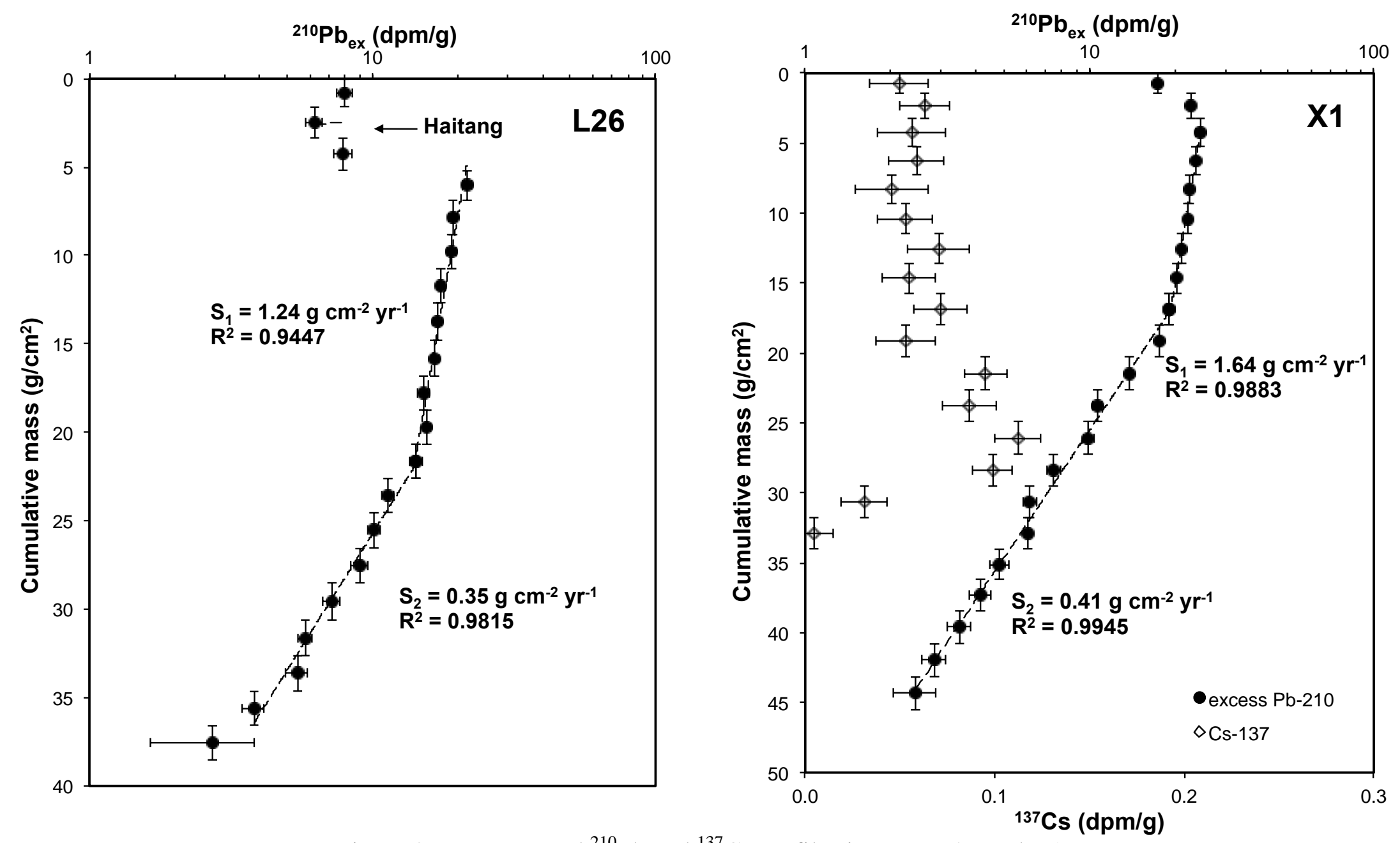

Figure 2. Unsupported ${ }^{210} \mathrm{~Pb}$ and ${ }^{137} \mathrm{Cs}$ profiles in cores L26 and $\mathrm{X} 1$. 


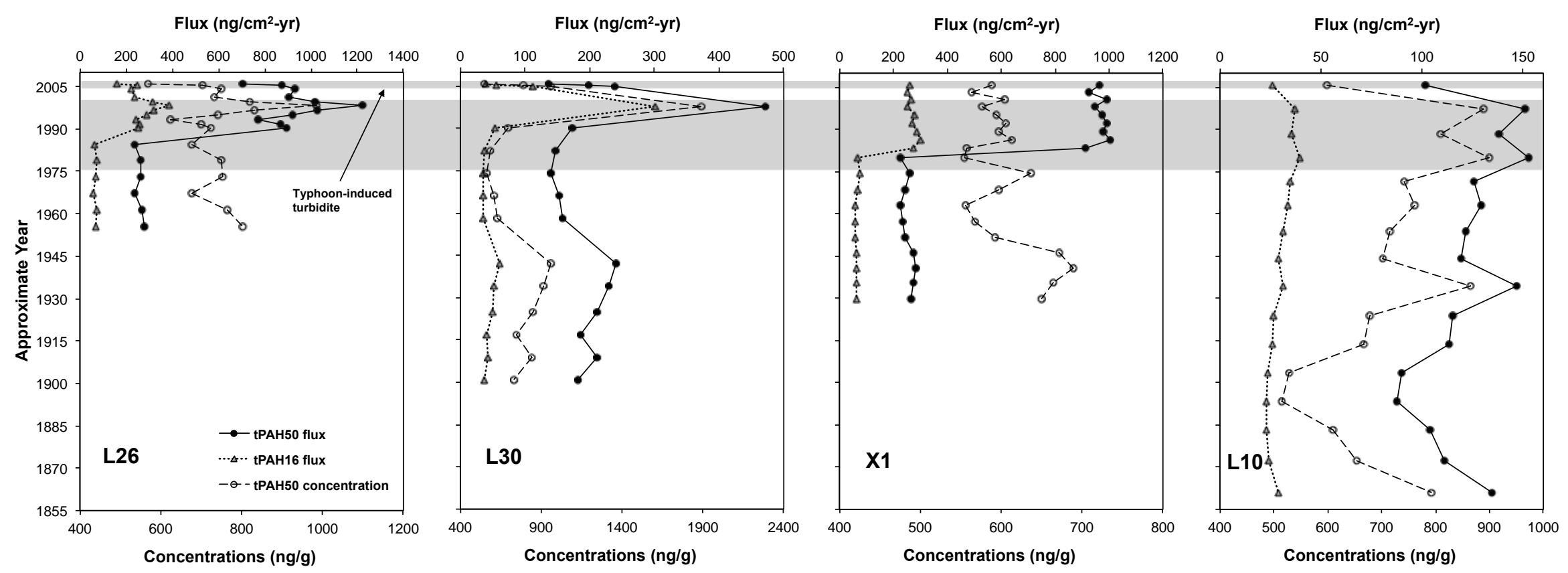

Figure 3. Temporal trends of total PAHs concentrations and fluxes at core sites L26, L30, X1, and L10. 
Phe/An

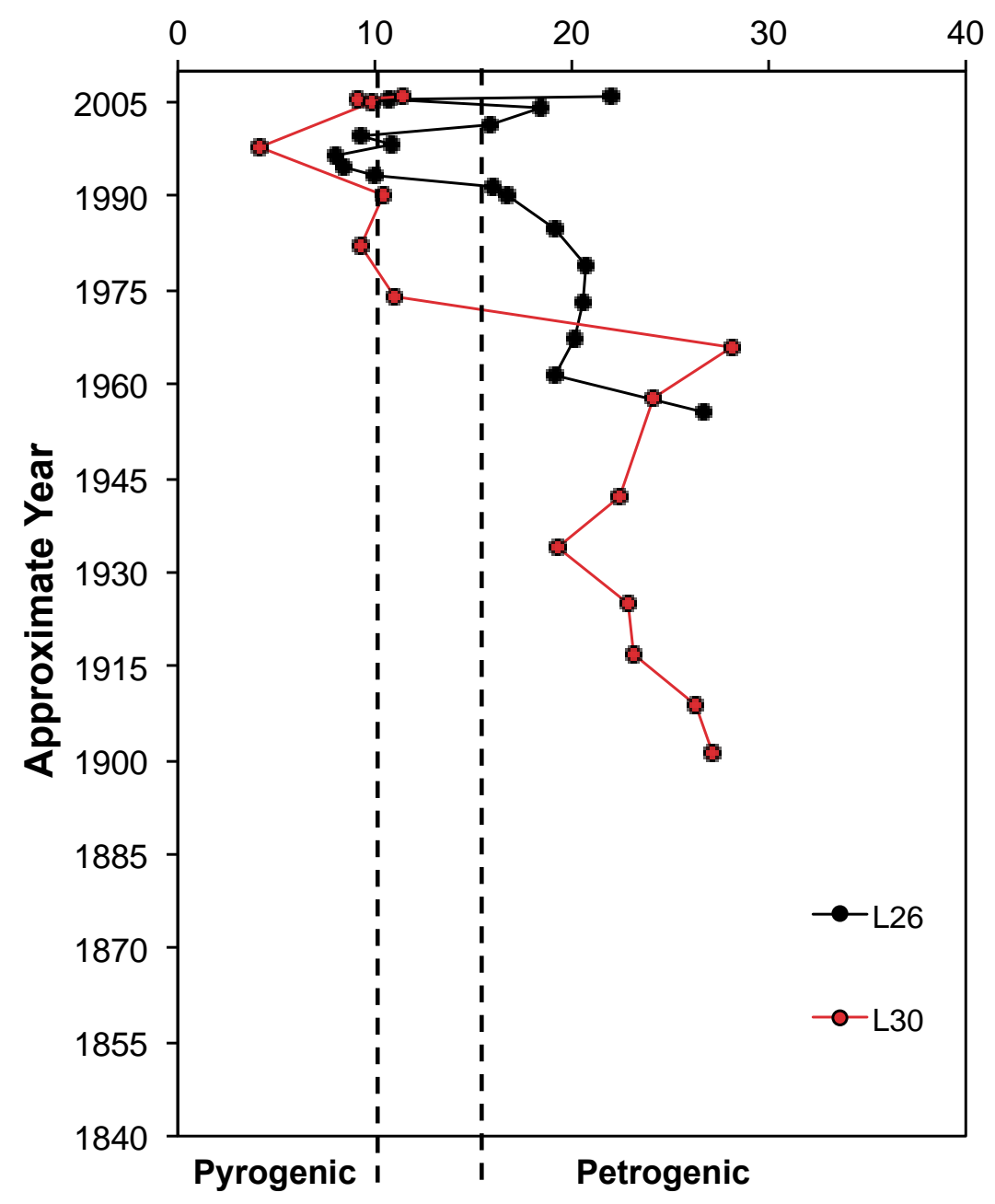

Phe/An

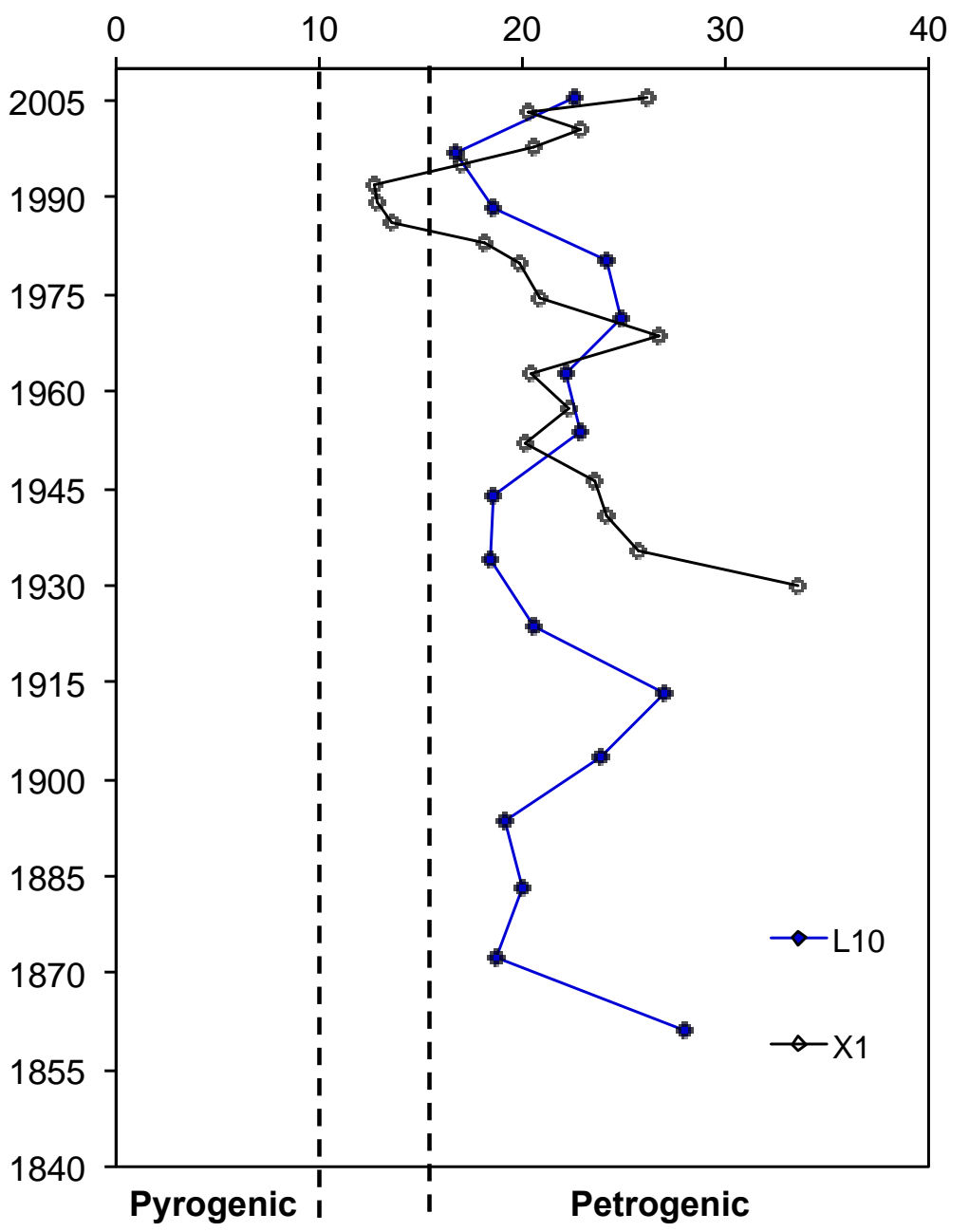

Figure 4. Vertical profiles of ratio of phenanthrene to anthracene (Phe/An) in cores L26, L30, X1, and L10. 


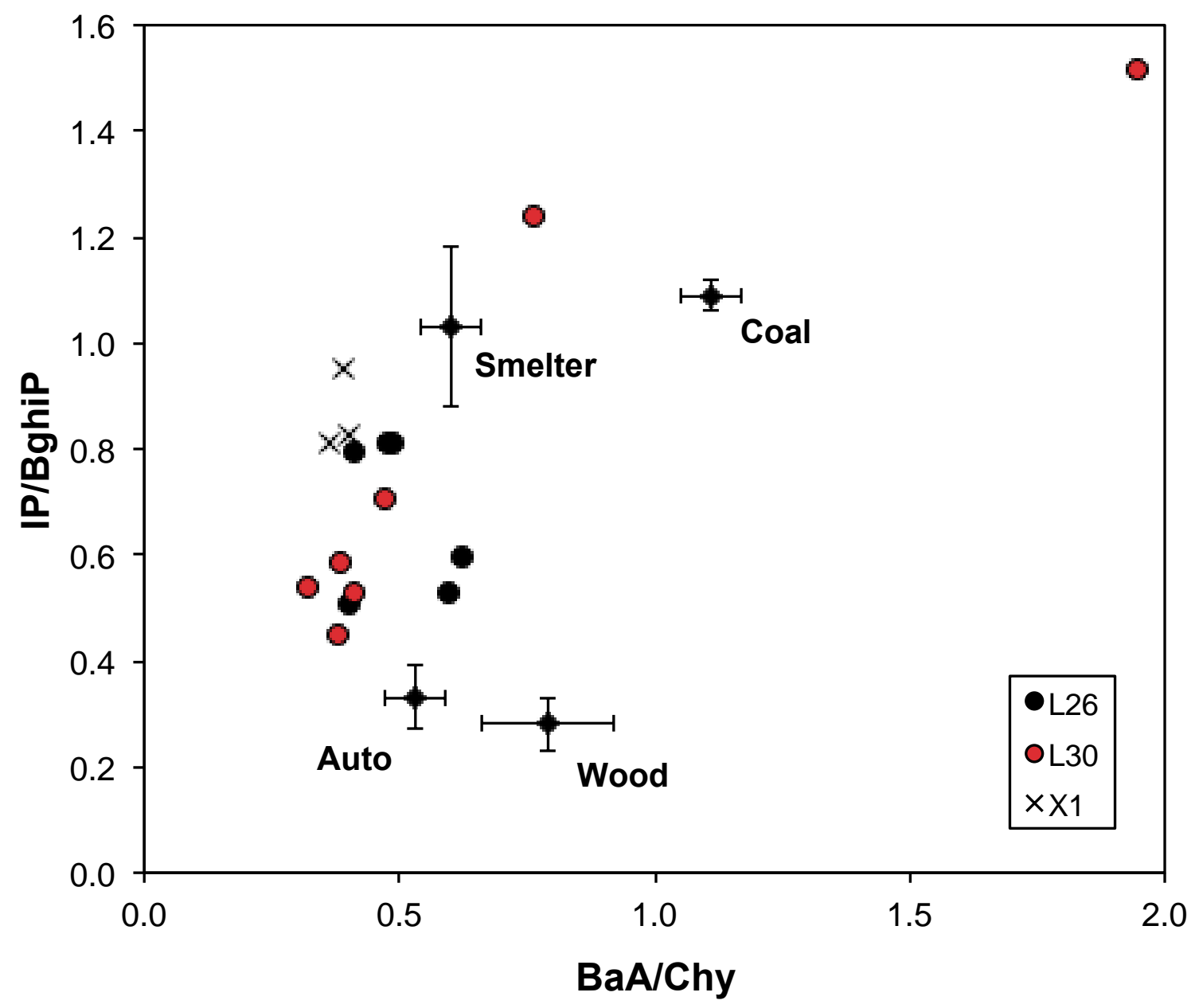

Figure 5. Specific PAH isomer ratios: Benzo[a]anthracene to Chrysene+triphenylene (BaA/Chy) vs. Indeno[1,2,3-c,d]pyrene to Benzo[g,h,i]perylene (IP/BghiP) for qualitative discrimination of pyrogenic PAH sources in cores L26, L30 and X1. Source signatures from Dickhut et al. (2000). 

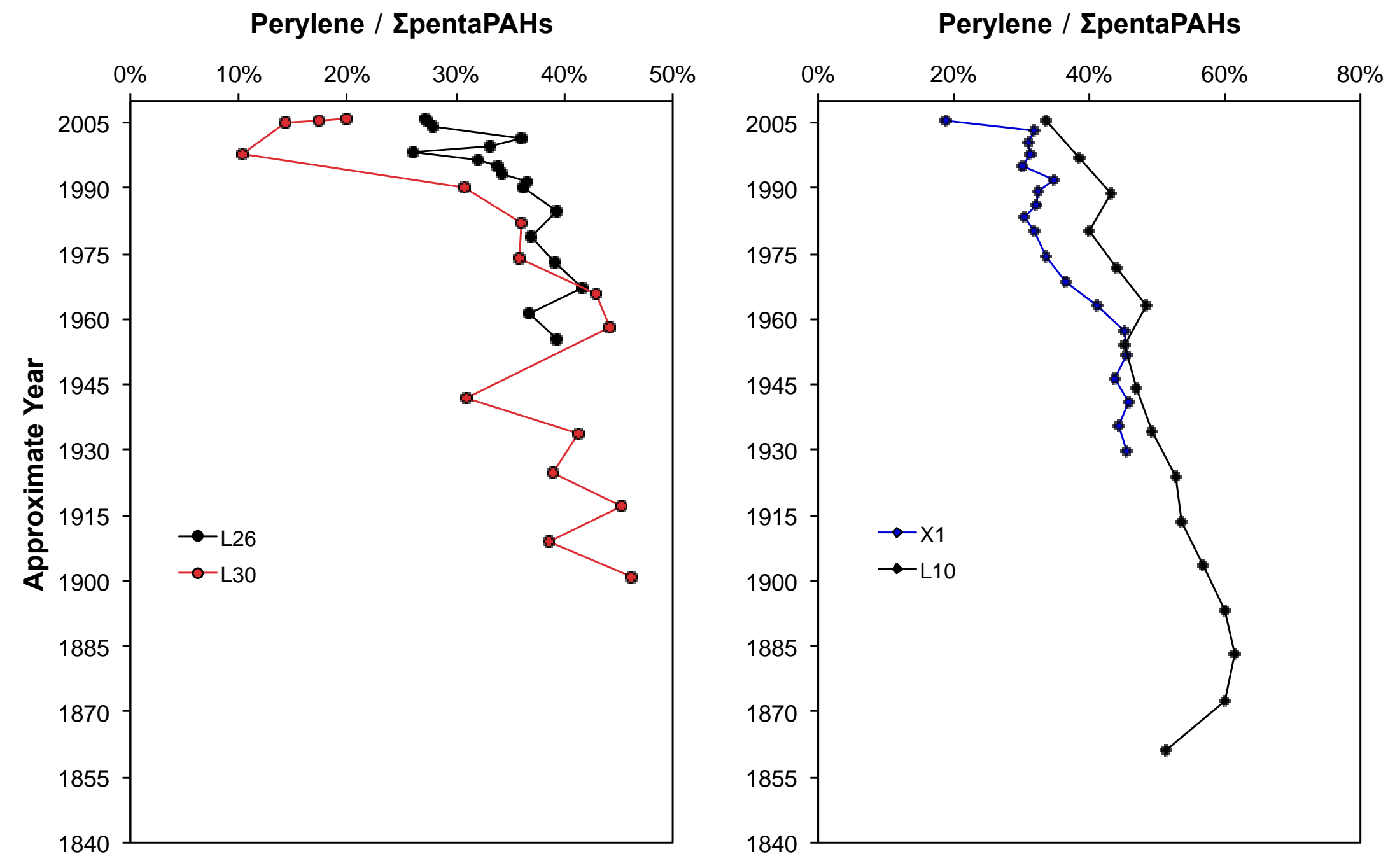

Figure 6. Vertical profiles of \% perylene in total penta PAHs in cores L26, L30, X1, and L10. 

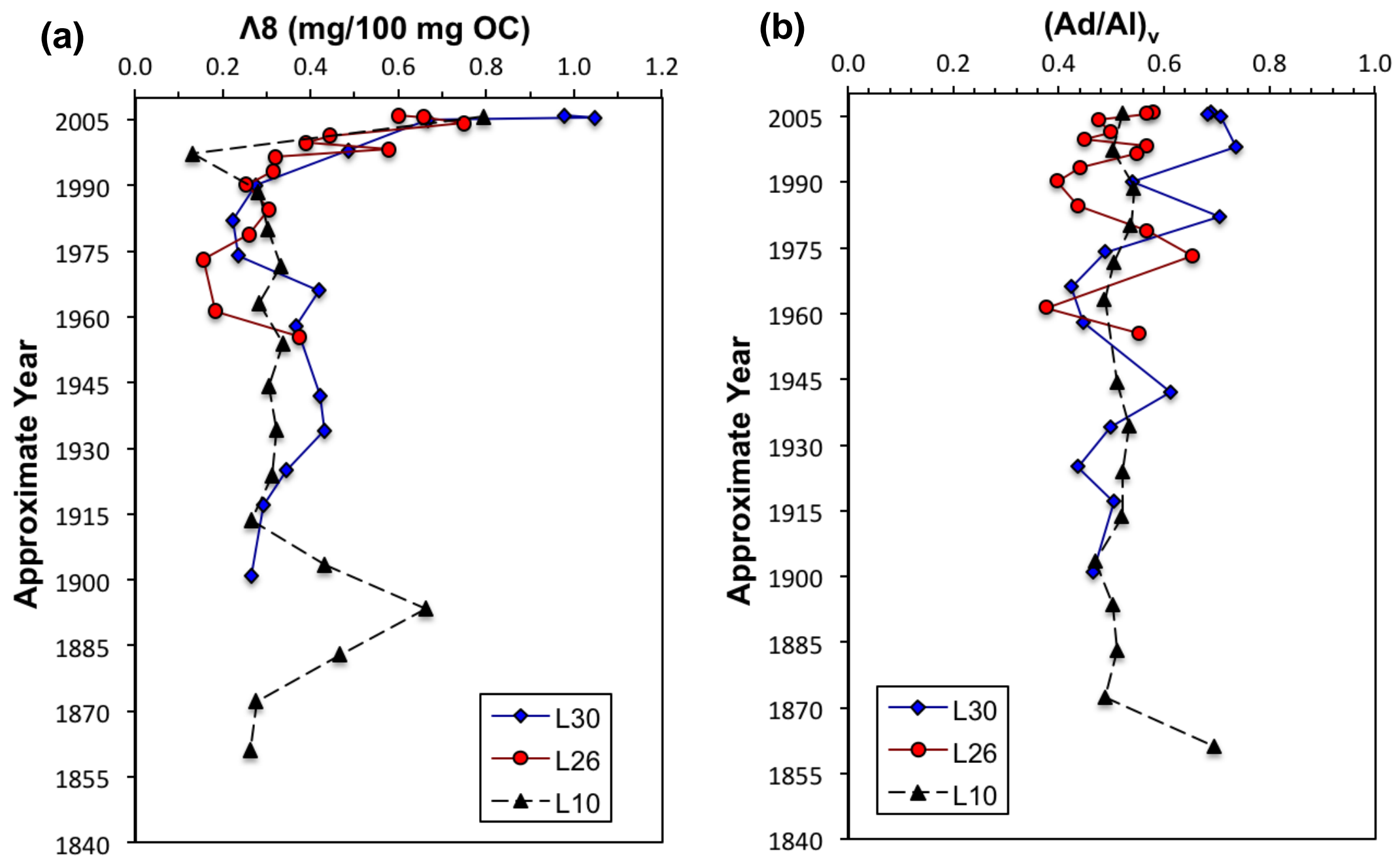

Figure 7. Vertical profiles of (a) $\Lambda 8(\mathrm{mg} / 100 \mathrm{mg}$ OC); and (b) ratio of vanillic acid to vanillin (Ad/Al) in cores L26, L30 and L10. 


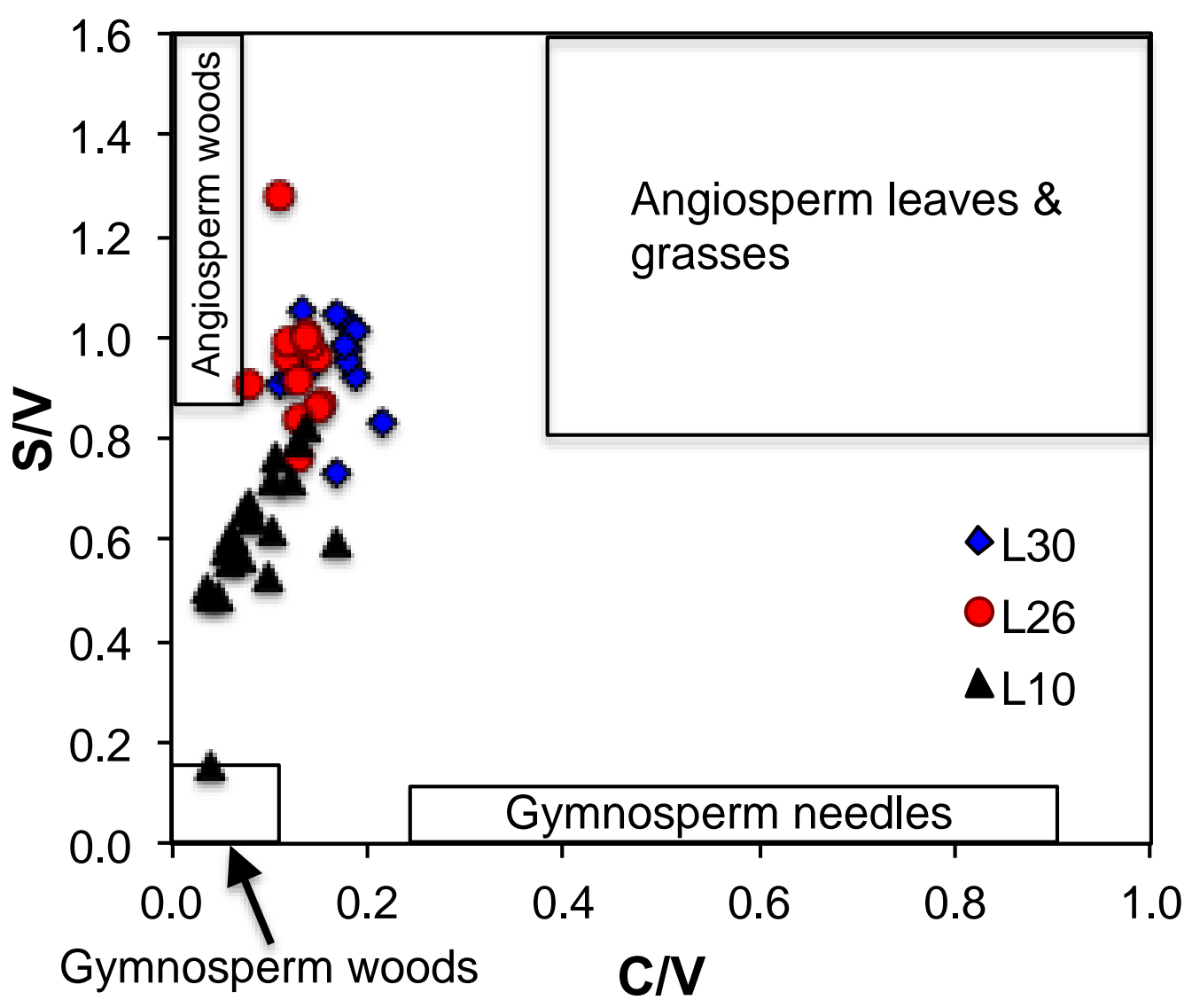

Figure 8. S/V vs. C/V plot for sediments from cores L26, L30, and L10. 